\title{
Dig into Information Literacy with Tools of Collaboration
}

\author{
Dr. Virginia L. Wallace \\ Instructor, School of Library \& Information Science \\ College of Mass Communications \& Information Studies \\ University of South Carolina \\ Columbia, South Carolina, USA
}

\begin{abstract}
One achieves more success at one's job when using proper tools. The more the tools are applied to tasks, the more they become second nature to the user. There are tools of collaboration that will help the school library media specialist and the teacher produce an environment of learning conducive to student achievement. By using these tools for the teaching of information literacy skills, the teacher and the school library media specialist can guide students through dynamic, rewarding, and successful inquiry-based, researchbased units of study. Four essential ingredients in the collaboration are partnership, planning, process, and product.
\end{abstract}

\section{Technology, Children, and Information Literacy}

Children are accessing web-based programs at a younger and younger age. Parents, watching their teens multi-task with cell phone, instant messaging, iPods, and laptops, believe erroneously that their children are skilled with the hardware and software. Having the ability to manipulate pieces of technology and to move from digital program to digital program does not an "information literate" student make.

Because parents feel inadequate on their children's technology playing fields, they allow them to develop poor information access habits. In 1989, Patricia Senn Breivik and E. Gordon Gee wrote Information Literacy: Revolution in the Library (American Council on Education, Macmillan). They contended that we were facing an information explosion for which we and our students were untrained. The authors encouraged school librarians to lead the "information literacy" mission.

In 1998, the ALA and AASL in Information Power touted the same message. Clearly, because of their training, school library media specialists should take the leadership role concerning strategies for developing student information literacy skills. However, because the school library media specialists perceived the methods in Information Power as beyond their influence base, information literacy remained a nebulous, uncertain goal.

By the turn of the 21st century, AASL had determined that they should train school librarians with sound pedagogical methods to be trainers of other school librarians within their states. The plan created an "information literacy flurry" in some states; yet a significant 
percentage of American school librarians do not have a copy of Information Power on their professional shelves nor have they read it.

Certain roles of school library media specialists are constants: teacher, information specialist, and program manager. However, school library media specialists will emphasize the teaching more and more since they are teachers whose classrooms are the largest in the schools and should be the most curricularly supportive. In order to carry out the role of teacher engaged in the curriculum, school library media specialists must wear the mantles of leadership, technology, and collaboration. Through change, the school librarian can realize that assuming leadership positions within the school's curriculum development and using technology as an instructional tool lead to collaboration.

\section{Tools of Collaboration: Partnerships}

Collaboration, more than cooperation, more than coordination, more than consensus, epitomizes "the whole is greater than the sum of its parts." Collaboration exemplifies "Two heads are better than one." Partnerships between the teacher and the school library media specialist can model teamwork for students. The partnerships, defined at first by two, can expand to include building curriculum coordinators, classroom coaches, and building technical coordinators. The work of the partnerships will interest other teachers. Recognizing the proactive leadership of the school library media specialists, building administrators will appoint them to serve on planning committees and on other curricular projects. From these changes, students will benefit. Enhanced teaching and learning will take place. Students will build lifelong learning skills even when technological formats and pedagogical trends change. Students become the benefactors of the partnership efforts instigated by the school library media specialist.

To initiate collaboration, the school library media specialist must seek a teacher pioneer, one willing to explore new territories. Remember: many teachers today are vague about information literacy - its definition, its educational role, their roles in relation to it, its place in one's yearly evaluation, and how it could impact state standardized test scores. Therefore, it is vital that the school library media specialist (SLMS) familiarize himself with the school's yearly curriculum map and review the various texts used within each grade level in order to approach the teacher as a knowledgeable team player. No SLMS should take on the entire faculty in one year! As an advocacy tool, developing collaborative relationships may entail only four efforts the first year - one each marking period.

During this time, the SLMS can sow seeds among other faculty members: (1) He can build awareness that his understanding of the material to be covered during the curricular year is thorough and that his ability to add resources to any given unit is his area of expertise. (2) Inviting other classes as an audience for the concluding activity builds curiosity and future collaboration inquiries. Audiences of teachers and students, invited to share demonstrations of authentic assessment, see the possibilities for their own teaching and learning.

Time robs us all of creativity, depth of planning, well-ordered response to units of study, intervention so all students can be successful, and perusal of journals to stay current in our field. How often have educators said, "I don't have time"? Truth is we find time for what we prioritize. 
Therefore, school librarians must prioritize strengthening and maintaining and enhancing information literacy skills through collaboration.

Collaboration can be defined as the four P's: partnership, planning, process, and product. The 4 P's, when used together, form a cohesion that gives the partnership, anticipation and energy; planning, depth of purpose; process, clearness of direction; and product, meaningful expression of student learning. Collaboration, at the highest level of critical thinking teaching and learning, envisions the teacher and school library media specialist at their teaching best and students at their learning best.

\section{Tools of Collaboration: Planning}

\section{Needs Assessment}

As educators assess at the end of a unit of study so should they at the beginning. The two assessments differ but both are crucial pieces in the instructional planning and research process. At the beginning of the unit, rather than looking at a product or authentic representation of material learned, the teacher and SLMS share information about the teaching/learning needs of the students. Those needs result from the class culture, the class organization planned for each lesson, the academic levels of the students, students' behavioral responses, and students' abilities with technology, the written word, and group work.

The teaching partnership sometimes uses pre-tests before proceeding too far with the plan. The pre-test gives a clear picture of prior knowledge of the subject and student attitude toward the forthcoming work. With that information as well as an understanding of learning styles and classroom culture, the teacher and SLMS can design the unit of study. Their design, backward in nature, will give them concrete goals and objectives. They will delineate teaching and learning strategies and activities for attaining the goals established in the instructional design.

An early activity for clarification of work ahead could be the KWHL chart: What do I know? What do I want to know? How will I find what I need? What have I learned? The early explanation of the chart gives the student a quick outline of parts of the process and infers the use of resources. The student gets a sense of time for the unit and product. Because children and teens inundate themselves with images - cell phone video, movie theatres, CD's, DVD's, videotapes, iPod visuals, Internet, and electronic games - the KWHL is a non-threatening way to introduce a unit because it can be laid out as a chart and thus, becomes visually more appealing to the students.

\section{Bloom's Taxonomy and Anderson's Revised Taxonomy}

Bloom's Taxonomy, a multi-tiered model of classifying thinking according to six cognitive levels of complexity, provides a developmental scaffold for critical thinking in an inquiry-based environment. Knowledge, comprehension, and application represent the lower level. The higher three levels are analysis, synthesis, and evaluation.

Anderson's Revised Taxonomy covers remembering (comparable to knowledge), understanding (comparable to comprehension), applying (application), and analyzing (analysis). To this point, they are parallel but notice that Anderson places evaluation (evaluation) before 
creating (synthesis). Creating as the highest level of cognitive development reflects the emphasis today on authentic assessment. Students "create" a product that demonstrates the student's competency with the subject matter. The creating allows the student to put his learning into a situation that he feels is real. He sees its applicability to his future place in society as a lifelong learner and as a productive wage earner.

\section{Instructional Design}

Before the SLMS and the teacher embark on a research-based unit assignment, in their planning, they must project to their goals. What purpose will the unit serve? What outcomes are expected for the students? The concept of backward design is not new; however, teachers have frequently not documented their planning. If stated and written, the backward design takes on a clear identity. Within this framework, any educator studying the plan of the unit would understand expectations. Such instructional design "centers on the research process" (Kuhlthau, 2001).

The partnership's plan must include formative evaluations throughout the unit of study; and from the outset, the students should understand how summative evaluation would occur. When the teacher introduces the unit, he shares a rubric for evaluation of the student product. More students take ownership for their work because they can see exactly what it takes for exemplary work versus adequate work versus weak work. Often a constructivist approach is the best tool for this type of student performance. It usually means encouraging students to use active techniques (experiments, real-world problem solving) to create more knowledge and to reflect on and talk about what they are doing and how their understanding is changing.

Within the United States, in all public educational establishments, the state tests drive teaching and student outcomes. The tests and their content remain a teaching focus while the partnership's planning allows students explorative and creative opportunities. To keep the content centered, the teacher and SLMS offer instructional intervention when appropriate and needed. Students leave high school with only as many research skills and critical thinking skills as teachers (classroom \& school library) give them. With well-planned classroom units of study, the students learn HOW TO LEARN.

\section{Tools of Collaboration: Process}

What process? A process for both the SLMS and the teacher and for the students. The process for the partnership is their instructional design. The process for the students requires a research model that focuses on an inquiry-based approach. The hope is to slay the "report." Reports do not use higher order thinking skills. Reports use questions, such as who, where, when, and what. Reports are a regurgitation usually accomplished through copy and paste. 


\section{Inquiry-based Teaching \& Learning with Essential Questions}

The inquiry-based process uses who, where, when, and what as foundation or framing questions. These questions become the basis for deeper exploration and learning. Both the teacher and the SLMS would want answers to these questions firmly in line with students' thinking as they embark on the new knowledge-building unit. The answers to the framing questions indicate prior knowledge, needed in order to tackle the Essential Questions. Essential Questions involve critical thinking because they require more than one word or one-phrase answers. Nor can they be answered with "yes" or "no." Students must "dig" - must inquire, must research - to answer these questions, such as why, what if, and how. Additionally, comparison and contrast make good higher order thinking skill scenarios.

Objectives for an inquiry-based lesson would utilize actions, such as Recognizing and Recalling to establish the frame for the scaffolding of the lesson. Interpreting, Exemplifying, Classifying, Summarizing, Inferring, Comparing and Explaining make a bridge from the Prior Knowledge to work, study, research, and use of resources on a higher thinking plain with actions such as Executing, Implementing, Differentiating, Organizing, and Attributing. The uppermost reaches of the scaffold require Checking and Critiquing and Generating, Planning, and Producing.

With such a hierarchy, teachers and school library media specialists can participate in the teaching according to their expertises. Collaboration can take students and teachers beyond "doing school" (Alewine, SC DOE library coordinator). As student competencies with the process grow, so will active learning and inventive thinking. We want each high school graduate to typify adaptability, self-direction, curiosity, rigor, creativity, risk taking, and sound reasoning. We call these 21 st Century skills for productive, satisfactory, and self-directed lives.

\section{Research Model}

In South Carolina, as in several states, the Department of Education suggests the use of the Big6 as the research model of choice. Several reasons led to this decision: (1) its non-linear functionality (2) alignment to AASL national standards and ISTE NETS (International Society for Technology Education's National Educational Technology Standards) (3) its adaptability to all curriculum areas and the corresponding subject standards (4) its constructivist capabilities (5) its problem-solving logic and (6) the parallelism with the scientific method and the writing process. As an inquiry-based process, the Big6 tool helps students formulate a plan of action for the problem's solution in a way that draws on their ideas, allows for inferences, taps into their prior knowledge and guides them toward successful conclusions. The Big6 can aid the teacher and school library media specialist to transform students from passive recipients to active participants in their learning.

The six steps are as follows:

\begin{tabular}{|l|l|}
\hline Task Definition & What needs to be done? \\
\hline Information Seeking Strategies & What can I use to find what I need? \\
\hline Location and Access & Where can I find what I need? \\
\hline Use of Information & What information can I use? \\
\hline Synthesis & How can I put my information \\
\hline
\end{tabular}




\begin{tabular}{|l|l|}
\hline & together? \\
\hline Evaluation & How will I know if I did my job well? \\
\hline
\end{tabular}

A look at three of the standards of the International Reading Association (IRA) and National Council of Teachers of English (NCTE) reveals a correlation with the Big6.

is Students conduct research on issues and interests by generating ideas and questions and by posing problems. They gather, evaluate, and synthesize data from a variety of sources (e.g., print and nonprint texts, artifacts, people) to communicate their discoveries in ways that suit their purpose and audience.

is Students use a variety of technological and information resources (e.g., libraries, databases, computer networks, video) to gather and synthesize information and to create and communicate knowledge.

is Students participate as knowledgeable, reflective, creative, and critical members of a variety of literacy communities.

Carol Kuhlthau in her keynote remarks at the IASL 2001 Conference suggested terminology slightly varied from the Big6 but the intent of the research process is intact. She called them the six C's for constructing a personal understanding in the process of information: Collaborating, Conversing, Continuing, Choosing, Charting, and Composing. Teachers and school library media specialists modify the language of the process to fit the learning styles within a class or the preeminent intelligences of the students.

\section{Use of resources}

Since a plethora of materials exist for any one topic, having the ability to sift the good from the bad, the appropriate from the inappropriate, the true from the false, and the biased from the objective becomes a developmental skill for public school students from Kindergarten through grade 12. Evaluation components include authority/credibility, validity/accuracy, reliability/dependability, currency/timeliness, appropriateness/relevancy, and coverage/thoroughness. The degree of difficulty for tackling the evaluative components increases as the students' level of learning concerning the research process increases.

Agosto's study (2002, cited in Thomas) reminds educators that for all the research direction and skills development given by the teacher and SLMS, the student will settle for information that is "good enough" rather than attempt to find the best information. Time constraints and loss of personal interest contribute to this approach. The attention span of our youth has narrowed because of instant gratification. Exposure to soundbites and quick fixes and edutainment has created a lack of patience. One helpful motivational model is ARCS:

1. Get the students' attention. $=$ Plan good assignments. Relate to students' experiences and needs.

2. Make the assignment relevant. $=$ Give students a choice.

3. Create confidence in students' abilities to accomplish the task $=$ Offer guidance and opportunities for success..

4. Seek student satisfaction as one of the goals of the instructional design $=$ Encourage student ownership. 
To inspire the development of higher order thinking skills needed for resource evaluation, the teacher and SLMS must teach continually and expect critical appraisal of resource choices. It is a circular system: teach critical appraisal; evaluate choice of resources; inspire higher order thinking (HOT); expect critical appraisal of sources, evaluate sources and around and around it goes until not only do the students own their questions, they own their own learning (Donham, 2001).

\section{Tools of Collaboration: Product}

\section{Synthesis \& Alternative Assessment Tools}

The transformation of researched and retrieved information into a new knowledge schema should involve the sharing of the product created. A student's synthesis decision, made from the choices given by the teacher and SLMS in the initial steps of the process, would reflect his confidence in working alone, his ability to meld with a group's dynamics, or his preference to collaborate with one other as the teacher and SLMS have done. Class organization benefits from such variety of choices. The teacher and SLMS will need to be vigilant concerning choices. No student should prepare his authentic assessment in the same way each time. He must learn to adapt and grow in his interactions and interplay with others or in his ability to begin and complete successfully a project on his own.

This stage of the teaching/learning process, comprised of the results of the research process, can utilize multiple technology hardware and software pieces. However, authentic assessment does not limit itself to technology. Worthwhile alternative assessment pieces could be skits, original poetry, monologs, bulletin boards, scrapbooking, posters, realia, original games, and interviews.

Increased inventory of hardware and peripherals in schools and of software purchased by school districts and/or found free on the Internet provide numerous technology possibilities. Below is a partial list of software for consideration:

- Portfolios

- PowerPoint

- Desktop Publishing (brochures, flyers, bookmarks)

- Digital Video

- Digital Photography

- Digital Gaming

- Pathfinders

- Webquests http://webquest.org/

- Graphic Organizers

- Portaportals

- Zoomerang (surveys, polls)

- Quia (Quizzes)

- Products for multi-modal presentations, such as Audacity, Photostory, StoryCorps, Microsoft Movie Maker, YouTube, and Flickr

- Multiple types of puzzles using Puzzlemaker http://www.puzzlemaker.com/ 
- Online Jeopardy www.mcps.k12.md.us/departments/elearning/templates/ppt/Jeopardy.ppt

- Augmented Reality

School library media specialists feel an urgency to stay current not only to help the students but also to assist the teachers. The SLMS might not use the hardware and/or software on a regular basis but he must stay apprised of technology trends and products. The digital divide has narrowed. For students without home computers, schools offer computer use time before, during, and after school. For those students who own the latest technology product, their final product might incorporate usage of an iPod for more than downloading songs. Worldwide Web projects for large group sharing are not a figment of imagination but concrete, viable possibilities with Web 2.0, such as the creating of wikis and/or blogs.

\section{Rubrics}

Teachers should not fear asking the question, "Can I offer my students enough variety for their learning styles?" The variety is available. The potential is evident. The instruction designed by partnership makes it happen. Within that design, they must create effective rubrics - rubrics that clearly discern the value levels of each component of the product.

Rubrics are under scrutiny because of poor construction. To design a good rubric, the collaborative team should ask questions to ascertain the highest level of expected performance. They should turn the questions into definitive, concrete evaluation statements that they explain clearly and thoroughly to the students. When the collaborators begin at the end with goals and objectives that are stated in the students' rubric, they answer the age-old question, "Can I make a fair assessment of performance with this tool or tools?"

\section{Tools of Reflection}

There is strength in reflection as a collaborative tool. Reflection is a look at the total package. What did the unit of study mean to the content standards? What would work better? What could be left out next time? What should be added? Teacher and school library media specialist must answer these questions together and individually.

Besides reflecting on the planning, process and product, they should reflect on their partnership. Should their roles have been different? Did they allow enough time to plan, prepare, and process? Were there areas of disagreement that could have been resolved with consensus rather than capitulation on one person's part? Did the timeline established for collaboration allow enough collaborative preparation?

The collaborating teachers should give the students time to reflect on two aspects: student response to the overall process, project, and product and their thoughts about their involvement, such as (1) What could I do better next time? (2) What did I like best about this study unit? (3) What did I like least? (4) How could I better utilize my time in the future? 


\section{Conclusion}

Collaboration between the teacher and the school library media specialist requires strategies for guiding inquiry and enabling students to use information for learning. What the students see modeled and taught, not just assigned, impacts their attitudes, behavior, and effort.

Good research and problem solving activities do not happen accidentally. Planning is key for the partnership. Process is vital for the plan and for students' experiences with research and resources. The product reflects students' involvement in the lesson and their level of engagement. The tools employed by the collaborators give students skills and reasoning capabilities for "digging" into location, access, and use of information. What begins as information becomes knowledge. After all, as stated in AASL's advocacy motto, student achievement is the bottom line.

\section{References}

Alewine, Martha. (2006). Information literacy skills, the Big6, and school library media specialists. Classroom presentation. Columbia, South Carolina: University of South Carolina.

American Association of School Librarians. (1998). Information power: Building partnerships for learning. Chicago: American Library Association.

Breivik, P. S. \& Gee, G. E. (1989). Information literacy: Revolution in the library. New York: American Council on Education, Macmillan.

Callison, Daniel \& Preddy, Leslie. (2006). The Blue book on information age inquiry, instruction and literacy. London, Libraries Unlimited.

Carr, Amy M. \& Carr, Chad S. (2000). View by theory: ARCS - motivation theory. Retrieved March 5, 2007 from, http://ide.ed.psu.edu/idde/ARCS.htm.

Donham, J., Bishop, K., Kuhlthau, C. \& Oberg, D. (2001). Inquiry-based learning: lessons from library power. Worthington, $\mathrm{OH}$ : Linworth.

Foster, Andrea L. (2007). New programs teach undergraduates how to use the Internet and the online card catalog in search of the best sources. The Chronicle of Higher Education: Information Technology. March 9, 2007. Retrieved March 10, 2007, from http://chronicle.com/weekly/v53/i27/27a03801.htm.

International Reading Association \& National Council of Teachers of English. (2002-2007). Readthinkwrite: IRA/NCTE standards for the English language arts. Retrieved February 27, 2007, from http://www.readwritethink.org/standards/index.html.

International Society for Technology in Education. (2000 - 2004). National educational technology standards for students. Retrieved February 16, 2007, from http://cnets.iste.org/students/.

Kuhlthau, Carol (2001). Rethinking libraries for the information age school: vital roles in inquiry learning. Retrieved February 28, 2007, from http://www.iasl-slo.org/keynote-kuhlthau2001.html.

Montiel-Overall, P. (2005). A theoretical understanding of teacher and librarian collaboration (TLC). School Libraries Worldwide, 11 (2), $24-48$.

Murray, Janet. (2002). Applying Big6 ${ }^{\mathrm{TM}}$ skills, information literacy standards and ISTE NETS to Internet research. Retrieved March 6, 2007 from, http://www.janetsinfo.com/big6info.htm.

Thomas, Nancy Pickering. (2004). Information literacy and information skills instruction. London, Libraries Unlimited.

\section{Biographical Notes}

Virginia Wallace, a former high school library media specialist, teaches at the University of South Carolina, School of Library and Information Science. Trained by the American Association of School Librarians, she has conducted numerous Advocacy seminars. Some of her proudest work has come from her work with student broadcast journalism. 